\title{
New archeological and geological data about St. Ivan and St. Peter islands, Black Sea
}

\section{Нови археологически и геоложки данни за остров Св. Иван и Св. Петьр, Черно море}

\author{
Stefan Velev ${ }^{1}$, Ivan Christov ${ }^{2}$ \\ Стефан Велев ${ }^{1}$ Иван Христов
}

${ }^{1}$ Sofia University St. Kliment Ohridski, Faculty of Geology and Geography, 1504 Sofia, Bulgaria; E-mail: velev@gea.uni-sofia.bg

${ }^{2}$ National Museum of History; 1618 Sofia; E-mail: ivchirstov70@abv.bg

\begin{abstract}
St. Ivan and St. Peter islands are located in the Black Sea at about $1200 \mathrm{~m} \mathrm{N-NW}$ of the old town of Sozopol. There are many archeological structures on the St. Ivan island, in the same time the data on the archeological heritage of the St. Peter island are very scarce. In this research we present information about the archeological and geological features of both islands, with the focus of St. Peter, and probable reasons why the islands are separated from each other from a geological point of view.
\end{abstract}

Keywords: geology, archeology, Black Sea.

\section{Introduction}

During regular archeological expeditions for nearly four decades, teams of several Bulgarian archeologists have worked at St. Ivan island. They discovered structures with a wide chronological range: a wall from the 4th-3rd century BC (Alexandrov, 2013); basilica of Holy Mother of God built at the end of the 5th and beginning of the 6th century (Petrinski, 2000); the medieval monastery of St. Joan Predtecha (Popkonstantinov et al., 2015).

On the neighboring island St. Peter, there is a sea sanctuary from which are preserved two structures created by accumulation of soil and stones, which look like two mounds (Hristov, 2022) (Fig. 1c, d). The ceramic fragments found during archeological works were probably brought separately to the island and were deposited synchronous with the accumulation of the embankments. Their dating is 5 th -4 th century BC. There are any artefacts that can be dated to other eras, and any remains on the island for the existence of a stone building, which can be associated with a supposed temple, chapel or larger church. Archeological data suggest that in the past, the two islands were jointed.
This research has two main geological goals. On one hand, to present new data about the geology of St. Ivan and St. Peter islands in the Black Sea, and on the other to formulate the geological reasons, why today they are separated.

\section{Geological background}

The studied area belongs to the eastern segment of the Sredna Gora magmatic and metallogenic belt. During the Late Cretaceous (Coniacian-Campanian) typical for the area is intensive magmatism, that generates huge volumes of plutonic and volcanic rocks. Magmatic processes are synchronous to the sedimentation and the result is a generation of different volcano-sedimentary rocks. Igneous rocks are concentrated mainly in the Strandzha and Michurin-Burgas volcano-plutonic regions. The most abundant rocks are volcanic, volcano-sedimentary and sedimentary varieties, separated in four groups - Varshilo, Grudovo, Michurin and Burgas group (Dabovski et al., 2008). The volcanic, volcaniclastic and volcanosedimentary lithologies are in a complex spatial and temporal relationships. Comagmatic subvolcanic and plutonic bodies are observed in the area. St. Ivan and 

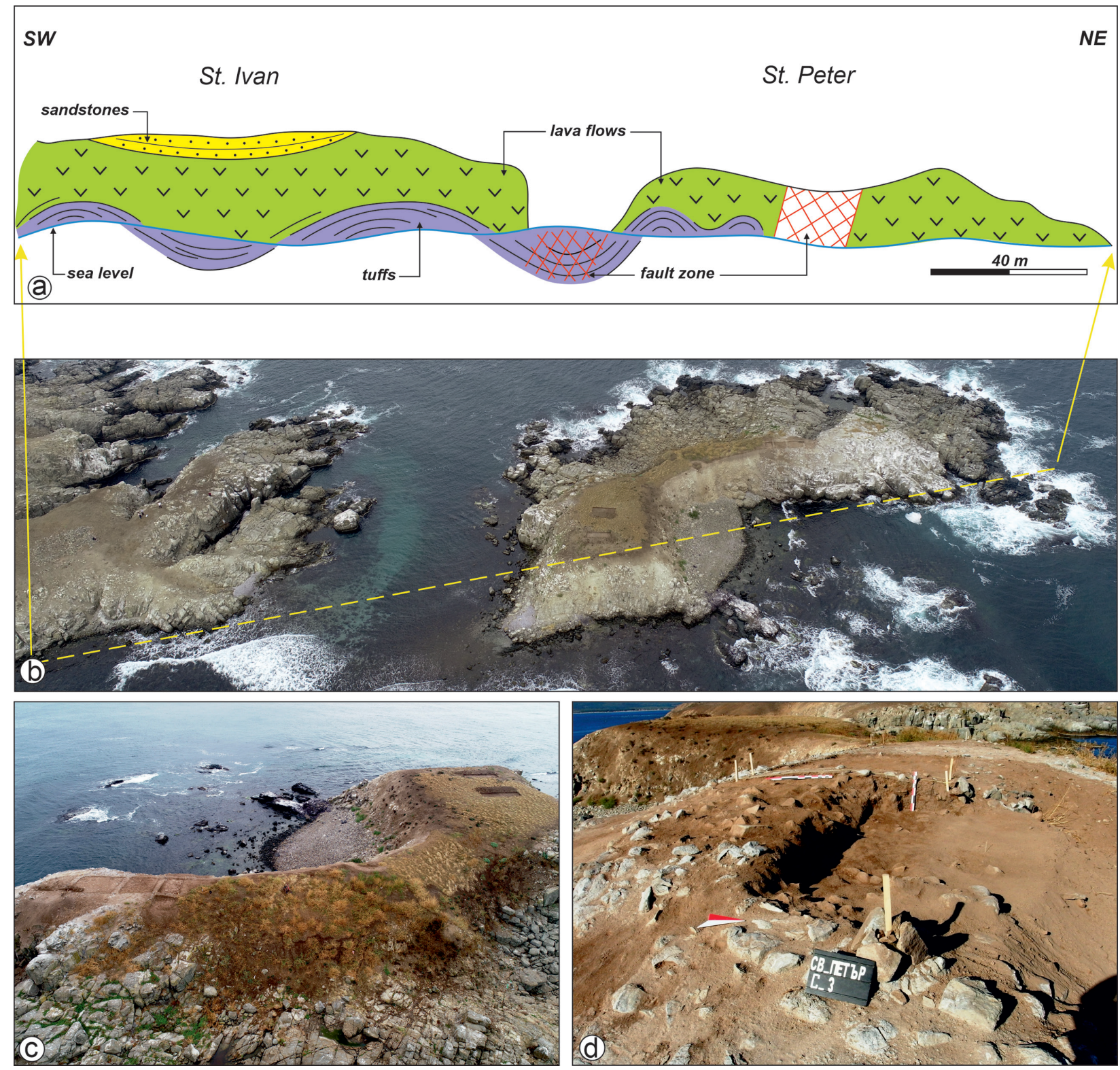

Fig. 1. St. Ivan and St. Peter islands: $a$, idealized geological cross-section through St. Peter and northeast part of St. Ivan islands; $b$, aerial photo of the islands (yellow dash line is the trace of the cross-section); $c$ and $d$, archeological structures of St. Peter island

St. Peter islands belong to the Burgas group, composed mainly of lavas and tuffs.

\section{Results}

St. Ivan and St. Peter islands are composed of three different rock types - tuffs, lava flows and sandstones. Lava flows are the most common rock species, and they almost build the islands (Fig. 1a). Probably there are two lava flows, each of which builds one of the two islands. The volcanic rocks are coherent and have massive texture, and probably are the primary reason for the formation of one big- ger island, before their separation. The thicknesses of the flows varies from $10 \mathrm{~m}$ to $25 \mathrm{~m}$. The rocks are dark grey, porphyritic with phenocrysts of plagioclase and pyroxenes. The plagioclase phenocrysts show strong alignment in one direction. The lavas overlay the tuffs and are covered by sandstones (Fig. 1a). According to the grain classification (Fisher, 1966) the tuffs are lapilli to ash tuff, with good stratification and layering. The sandstones are rare and crop out just on St. Ivan island.

Undoubtedly in the past, both islands were jointed. There are a lot of archeological facts supporting such assumption. Our geological data support 
this view as well. The main reason of separation of both islands is tectonic processes. Between the islands is traced big fault zone (Fig. 1a, b), probably of a strike-slip nature. Faulting combined with the sea water influence (salinity, wave activity etc.) have caused the separation of the islands. Except the faulting, important role played the physical and mechanical characteristics of the rocks, building up the space between both islands. There are extremely soft tuffs, which are readily destroyed by faults and erosion processes.

\section{Conclusions}

The archeological information about the Black Sea islands is very sporadic and superficial, combined with the lack of any detail geological studies. Most probable reason is the difficult access. This research is a very good example for collaboration work between archeology and geology.

\section{References}

Alexandrov, O. 2013. Ancient structures on the St. Ivan island near Sozopol. - In: Archaeological Discoveries and Excavations in 2012. Sofia, Colbis, 235-237; ISSN 1313-0889; COBISS.BG-ID - 1123846884.

Petrinski, I. 2000. The monastery "St. Ivan Predtecha and Baptist"of the St. Ivan island (1467-1629) - Bull. Burgas Nat. Mus., 3, 177-182.

Popkonstantinov, K., Ts. Drazheva, R. Kostova. 2015. The monastery "St. Joan Podrom" on the of St. Ivan island in the light of new archaeological research (2008-2013). Bull. Burgas Nat. Mus., 5, 209-217.

Hristov, I. 2022. Peninsula/Island of St. Thomas. History and Archeology of the Black Sea Islands. Veliko Tarnovo (in press).

Dabovski, Ch., B. Kamenov, D. Sinnyovsky, E. Vassilev, E. Dimitrova, I. Bairaktarov. 2008. Upper Cretaceous geology. - In: Zagorchev, I., Ch. Dabovski, T. Nikolov (Eds.). Geology of Bulgaria, vol. II, part 5, Mesozoic Geology, 355 p. (in Bulgarian with English summary).

Fisher, R. V. 1966. Rock composed of volcanic fragments and their classification. - Earth Sci. Rev., 1, 287-298; https:// doi.org/10.1016/0012-8252(66)90010-9. 